\title{
Metformin and ovarian cancer: the evidence
}

\author{
Elina Urpilainen ${ }^{1}$, Ulla Puistola ${ }^{1}$, Stergios Boussios ${ }^{2,3}$, Peeter Karihtala ${ }^{4,5}$ \\ ${ }^{1}$ Department of Obstetrics and Gynaecology, PEDEGO Research Unit, Medical Research Center Oulu, University of Oulu and University Hospital \\ of Oulu, Oulu, Finland; ${ }^{2}$ Department of Medical Oncology, Medway NHS Foundation Trust, Gillingham, Kent, UK; ${ }^{3}$ AELIA Organization, 9th \\ Km Thessaloniki - Thermi, Thessaloniki, Greece; ${ }^{4}$ Department of Oncology and Radiotherapy, Medical Research Center Oulu, Oulu University \\ Hospital and University of Oulu, Oulu, Finland; ${ }^{5}$ Department of Oncology, University of Helsinki and Helsinki University Hospital Comprehensive \\ Cancer Centre, Helsinki, Finland \\ Contributions: (I) Conception and design: All authors; (II) Administrative support: None; (III) Provision of study materials or patients: None; (IV) \\ Collection and assembly of data: None; (V) Data analysis and interpretation: None; (VI) Manuscript writing: All authors; (VII) Final approval of \\ manuscript: All authors. \\ Correspondence to: Peeter Karihtala, MD, PhD. Department of Oncology, Helsinki University Hospital Comprehensive Cancer Centre, P.O. Box 180, \\ FI-00029 Helsinki, Finland. Email: peeter.karihtala@oulu.fi.
}

\begin{abstract}
In recent decades, great interest in the off-label use of metformin has arisen as a result of its broad effects on different signaling pathways, with only a few side effects, and low cost. Metformin has been shown to have multiple, dose-dependent preclinical anticancer effects, which can be roughly divided into either direct effects via inhibition of mitochondrial respiratory chain complex I, or indirect effects through lowered glucose, insulin and insulin-like growth factor levels. Further details on in vitro and in vivo anticancer effects specifically in ovarian cancer are continuously reported. Preclinically metformin has clear chemosensitizing effects in ovarian cancer and it is an effective negative regulator of angiogenesis. There are also some epidemiological studies on metformin use in ovarian cancer, but the results of these studies are not as promising as those preclinical studies would indicate. Most preclinical studies have involved metformin concentrations that are many times higher than the pharmacological doses used in patients, which might confound the clinical use of metformin as regards the above-mentioned aspects. In this review we evaluate preclinical and clinical evidence concerning metformin in ovarian cancer treatment.
\end{abstract}

Keywords: Diabetes; epidemiology; incidence; survival

Submitted Jan 27, 2020. Accepted for publication Apr 20, 2020.

doi: $10.21037 / \mathrm{atm}-20-1060$

View this article at: http://dx.doi.org/10.21037/atm-20-1060

\section{Introduction}

Galega officinalis, i.e., goat's rue or French lilac has been used to treat polyuria and other symptoms of diabetes for centuries (1). Metformin (1,1-dimethylbiguanide hydrochloride) was later extracted from this plant and it was found to have glucose-lowering activity more than 100 years ago (2). Metformin was officially introduced to diabetes treatment in 1957 (3). With few contraindications and strong evidence from clinical studies, along with usually manageable side effects, metformin is still the most widely recommended first-line medical treatment for type 2 diabetes (T2D) (4).
Drug repositioning or repurposing are defined as a method of finding novel diseases and target molecules for drugs with already existing indications (5). When successful, this may drastically save time and other resources compared with the traditional drug development. Some examples in the field of oncology are disulfiram and probably the most prominent example is aspirin in the prevention of colorectal cancer in patients with inflammatory bowel disease $(6,7)$. Metformin is increasingly used in off-label indications, such as polycystic ovarian syndrome, obesity and metabolic syndrome (8). In the mid 1970s it was shown for the first time that biguanides inhibit mammary carcinogenesis in female rats (9). Suggested anticancer effects of metformin 


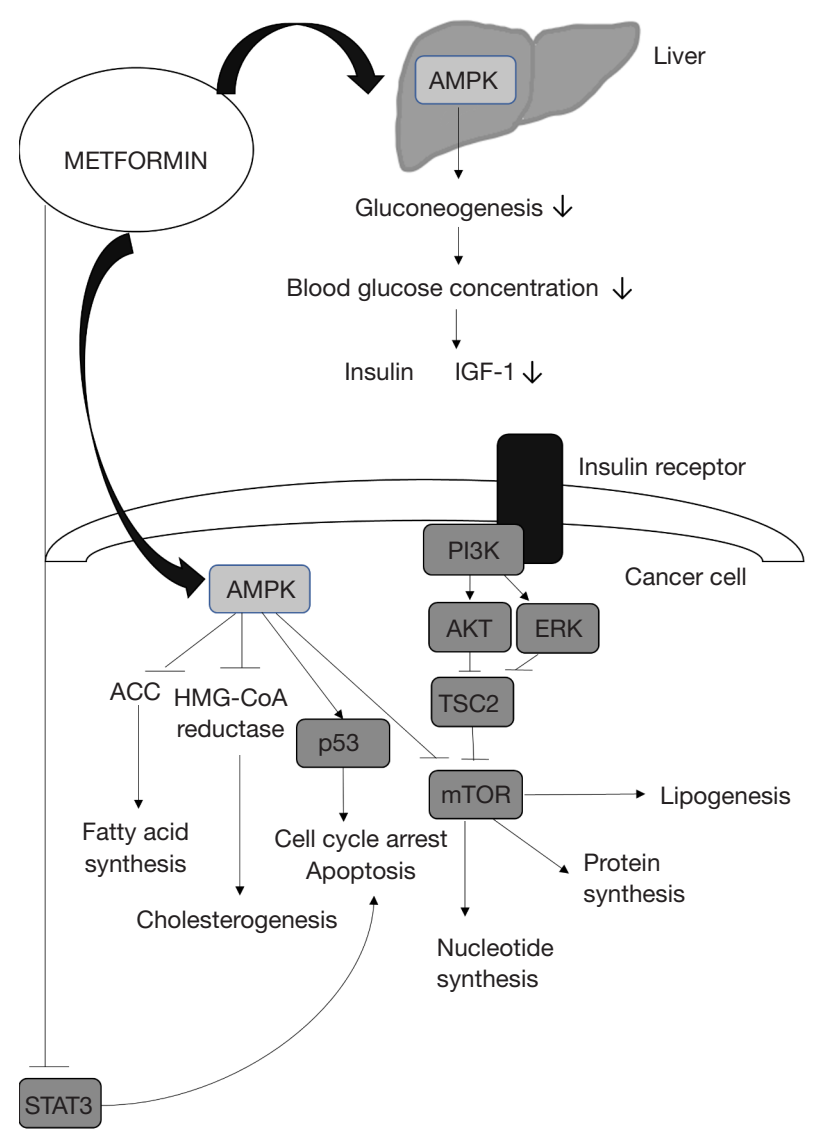

Figure 1 Metformin affects cancer cells both directly and indirectly. It activates AMP-activated protein kinase (AMPK), which leads, among other things, to inhibition of mammalian target of rapamycin (mTOR). It also sensitizes tissues to insulin, reduces hepatic gluconeogenesis and decreases circulating insulin levels. This leads indirectly to reduced phosphatidylinositol-3-kinase (PI3K) signaling. In addition, metformin deactivates the downstream signaling molecules ERK and STAT3, which have effects on cell growth and apoptosis (8,12,13). IGF-1, insulin-like growth factor 1; ACC, acetyl-CoA carboxylase; HMG-CoA, 3-hydroxy-3-methyl-glutaryl-coenzyme A; p53, tumor protein p53; AKT, serine/theonine-specific protein kinase; ERK, extracellular signal-regulated kinase; TSC2, tuberous sclerosis complex 2; STAT3, signal transducer and activator of transcription 3.

have drawn increasing attention during the last decade, mostly in breast cancer, but also considerably in the context of ovarian cancer (8). In the field of epidemiology, great interest in the possible role of metformin as a cancerpreventive agent arose in 2005 when an observational study from Scotland was published in which metformin use was related to a lower risk of cancer in general (10). At present, ovarian cancer patients are being recruited to take part in multiple randomized studies to evaluate the clinical efficacy of metformin (11). In this review, we will address the up-todate preclinical and clinical evidence concerning metformin in the context of ovarian cancer.

\section{Preclinical studies}

\section{AMPK patbway}

In theory, metformin may have great potential as a drug to use in cancer prevention. Its anticancer effects have been traditionally divided into direct and indirect effects, although novel mechanisms of action are continuously emerging (Figure 1) (14). As a direct action against cancer growth, metformin reduces the energy consumption of (cancer) cells by inhibiting mitochondrial respiratory chain complex I (15). As an indirect anticancer effect, metformin reduces fasting plasma insulin levels and attenuates insulin resistance by 
Table 1 Studies concerning the effects of metformin on ovarian cancer growth in preclinical models

\begin{tabular}{|c|c|c|}
\hline Authors, year & Setting & Main result \\
\hline Shank et al. 2012 (22) & $\begin{array}{l}\text { A2780 and SKOV } 3 \text { cells and xenografts } \\
\text { treated with metformin }\end{array}$ & $\begin{array}{l}\text { Metformin reduced cancer stem-cell growth, angiogenesis and } \\
\text { proliferation }\end{array}$ \\
\hline Kim et al. 2015 (23) & SKOV3 cells treated with metformin & $\begin{array}{l}\text { AxI and Tyro } 3 \text { were suppressed and Erk and STAT3 activated afte } \\
\text { metformin treatment }\end{array}$ \\
\hline Patel et al. 2015 (24) & $\begin{array}{l}\text { Metformin-treated primary human ovarian } \\
\text { carcinoma cells }\end{array}$ & $\begin{array}{l}\text { Metformin induced cell-cycle arrest and apoptosis, in which the } \\
\text { Bcl-2 family had an essential role }\end{array}$ \\
\hline Huo et al. 2017 (25) & $\begin{array}{l}\text { The effect of metformin in SKOV3 and } \\
\text { A2780 cells }\end{array}$ & $\begin{array}{l}\text { Metformin decreased cell viability and clone formation in both ce } \\
\text { lines. }\end{array}$ \\
\hline Fu et al. 2017 (26) & SKOV3 cells treated with metformin & $\begin{array}{l}\text { Metformin suppressed PI3K/AKT/mTOR signaling and triggered } \\
\text { cell-cycle arrest. The IC50 value was } 20 \mathrm{mmol} / \mathrm{L}\end{array}$ \\
\hline Erices et al. 2017 (27) & $\begin{array}{l}\text { In vitro study on the relation of metformin } \\
\text { and platelets }\end{array}$ & $\begin{array}{l}\text { Metformin had anti-platelet effects, which led to decreased } \\
\text { angiogenesis. Micromolar concentrations of metformin had no } \\
\text { impact on proliferation }\end{array}$ \\
\hline Zhang et al. 2018 (28) & $\begin{array}{l}\text { Apoptosis and invasion were studied after } \\
\text { metformin treatment of OVCAR- } 3 \text { cells. } \\
\text { siRNA against Cyr61 was used }\end{array}$ & $\begin{array}{l}\text { Metformin improved chemosensitivity by targeting the Cyr61/ } \\
\text { PI3K/Akt/mTOR axis }\end{array}$ \\
\hline Ma et al. 2019 (29) & $\begin{array}{l}\text { Three ovarian cancer-cell lines and } \\
\text { xenografts treated with metformin. Special } \\
\text { interest in the role of ASK1 }\end{array}$ & $\begin{array}{l}\text { Metformin cytotoxicity was dependent on glucose levels and wa } \\
\text { mediated by ASK-1 }\end{array}$ \\
\hline Zou et al. 2019 (30) & SKOV-3 cells treated with metformin & $\begin{array}{l}\text { Metformin suppressed invasion and migration capabilities and } \\
\text { attenuated proliferation }\end{array}$ \\
\hline
\end{tabular}

Erk, extracellular-signal-regulated kinase; STAT3, signal transducer and activator of transcription 3; PI3K, phosphoinositide 3-kinase; mTOR, mammalian target of rapamycin; Cyr61, cysteine-rich angiogenic inducer 61; siRNA, small interfering RNA; ASK1, apoptosis signal-regulating kinase 1.

increasing skeletal-muscle glucose uptake. This leads not only to metformin's actual therapeutic effect, decreased blood glucose levels, but also cuts hyperinsulinemia. This may have effects on malignant cell mitogenesis and survival, since the association between insulin and insulin-like growth factor (IGF) in carcinogenesis has been repeatedly demonstrated (16), and cancer cells often show high-level expression of insulin receptors (14). Both indirect and direct routes are mediated by the cellular energy-status monitor adenosine monophosphate-activated protein kinase (AMPK), which under energy depletion is activated, switching the cell from an anabolic to a catabolic state (14). Metformin also very effectively attenuates p53 and mTOR signaling routes via AMPK $(8,17)$. In the end, this leads to various growth-inhibiting properties including anti-mitotic and anti-inflammatory effects (18). AMPK activation has been suggested to play a most prominent role in the tumorsuppressing effects of metformin $(19,20)$. LKB1 is a tumor suppressor gene with relevance to epithelial neoplasia.
Beyond AMPK, the metformin-stimulated activation of LKB1 as well takes place in hepatocytes, and loss of its function is associated with Peutz-Jeghers syndrome (21).

\section{PI3K/AKT/mTOR signaling}

Of all the preclinically studied tumor types, one of the strongest indications supporting metformin's anticancer effects comes from ovarian cancer studies (Table 1). Metformin effectively suppresses PI3K/AKT/mTOR signalling, e.g., in OVCAR-3 and SKOV3 cells, and triggers cell cycle arrest at the G2/M checkpoint $(26,28)$. However, under hyperglycemic conditions metformin seems to have little or no anticancer effect in preclinical models, while low glucose levels enhance its cytotoxicity as a result of induction of ASK1-mediated mitochondrial dysregulation (29). mRNA and protein levels of the prosurvival and anti-apoptotic receptor tyrosine kinases Axl and Tyro3 are suppressed at transcriptional level when ovarian 
cancer cells are treated with metformin, and this leads to subsequent deactivation of downstream signaling molecules such as Erk and STAT3 (23). Indeed, STAT3 inhibition has been proposed as one of the most significant effects of the anticancer action of metformin in at least pancreatic and triple-negative breast cancers, although its dependence on mTOR signaling is still under debate (8). Metformin inhibits the AMPK-dependent growth of multiple ovarian cancer cell lines and inhibits several vital receptor tyrosine kinases of ovarian cancer, such as HER4, epidermal growth factor and platelet-derived growth factor receptor (31).

\section{Angiogenesis and stem cells}

Angiogenesis is a crucial hallmark of ovarian carcinogenesis and also important from the therapeutic point of view. Decreased angiogenesis in metastatic tissues, attenuated ovarian cancer-cell adhesion and dampened macrophage infiltration were observed under metformin treatment in vitro and in vivo in murine experiments $(32,33)$. Two other ovarian cancer studies showed that dampened neovascularization after metformin treatment can be driven either by blockage of the mTOR signaling pathway, or metformin's ability to reduce the angiogenic and other carcinogenic properties of platelets $(27,34)$. Intriguingly, from a clinical point of view, reduced angiogenesis was demonstrated using only micromolar concentrations of metformin. In other reports these near-pharmacological concentrations of metformin did not actually have any impact on proliferation in SKOV3, UCI101 or A2780 cell lines $(35,36)$. Metformin treatment in vitro has also effects on stem cell differentiation and growth. Metformin targets $\mathrm{ALDH}+$ ovarian cancer stem cell populations in vitro and in xenograft models, leading to suppressed angiogenesis and proliferation (22). A relatively low dose of metformin selectively inhibited CD44+CD117+ ovarian cancer stemcells through downregulation of epithelial-to-mesenchymal transition, without affecting the cancer-cell proliferation rate (36).

\section{Apoptosis and $p 53$}

Increased Bcl-2-protein family dependent apoptosis has been linked in many preclinical ovarian cancer studies to metformin's chemosensitizing effects $(24,32,37)$. Recently, additional mechanisms have also been revealed. Metformin may impede chemoresistance by targeting cancer stem cell populations and reducing the migratory properties of cancer via upregulation of taurine (38). On the other hand, the chemosensitizing effect of metformin seems to be crucially dependent on p53 function (39). In the presence of p53, metformin suppresses a major glycolytic enzyme, hexokinase II, and pyruvate dehydrogenase kinase, which is an antiapoptotic serine/threonine kinase of the same pathway. This leads to sensitization of ovarian cancer cells to metformin, which does not occur in the case of mutated p53. However, mutation of $\mathrm{p} 53$ is considered to be a driver mutation in high grade serous ovarian carcinoma and is present in more than $96 \%$ of cases (40). Thus, other pathways for apoptosis are likely to be involved in these cancers. On the other hand, metformin also seems to have capability to resensitize cisplatin-resistant or paclitaxel-resistant ovarian cancer cells to chemosensitive cells, possibly by induction of autophagy or via the anti-inflammatory properties of metformin $(27,41)$.

\section{Efficacy of metformin in cell-line and animal studies}

Although more than $70 \%$ of ovarian cancers respond to first-line chemotherapy (42), the majority of cases relapse and develop chemoresistance eventually (43). Multiple lines of evidence suggest that metformin can be used to overcome chemoresistance, especially cisplatin resistance, in ovarian cancer in vitro (Table 2). In one of the earliest studies, metformin was reported to enhance cisplatin activity in OVCAR-3 and OVCAR-4 cells. Metformin as a single agent was also demonstrated to reduce cancer cell proliferation in this work (44). The same group later showed that metformin induces cell cycle arrest and apoptosis in the same ovarian cancer cell lines by means of a mechanism that was independent of AMPK but dependent on Bcl-2-family proteins (37). These observations were later repeated in primary human ovarian carcinoma cells, isolated from ascitic fluid or omental metastases $(24,47)$. Metformin also induces growth inhibition and shows synergy with cisplatin in a time- and dose-dependent manner in more invasive SKOV3 ovarian cancer cells (30). In cisplatinresistant ovarian cancer patient-derived xenograft models, in vivo treatment with metformin partially reversed platinum resistance, although at a suprapharmacological dose of $400 \mathrm{mg} / \mathrm{kg}$ (48). Metformin also sensitizes ovarian cancers to paclitaxel in mouse models and induces cell death in SKOV3 cells or ovarian cancer primary cultures when treated with paclitaxel and carboplatin $(20,31)$.

It has to be noted that in most of preclinical studies the used metformin concentrations have been millimolar 
Table 2 Studies concerning the effect of metformin on ovarian cancer chemoresistance in pre-clinical models

\begin{tabular}{|c|c|c|}
\hline Authors, year & Setting & Main result \\
\hline Zheng et al. 2018 (45) & SKOV-3 cells treated with metformin & $\begin{array}{l}\text { Metformin decreased ovarian cancer (and metastatic) } \\
\text { growth and invasion and had synergy with cisplatin }\end{array}$ \\
\hline Yang et al. 2019 (41) & $\begin{array}{l}\text { Cisplatin-resistant SKOV3 cells treated with } \\
\text { metformin, methotrexate and/or cisplatin }\end{array}$ & $\begin{array}{l}\text { Metformin re-sensitized cells to cisplatin and } \\
\text { enhanced autophagy }\end{array}$ \\
\hline Erices et al. 2013 (35) & $\begin{array}{l}\text { A2780 and SKOV3 cell lines and primary } \\
\text { cultured cells treated with low micromolar } \\
\text { concentrations of metformin }\end{array}$ & $\begin{array}{l}\text { Pharmacological doses of metformin had synergy with } \\
\text { carboplatin, but not single-agent activity }\end{array}$ \\
\hline Lengyel et al. 2015 (31) & $\begin{array}{l}\text { The effect of metformin in vitro and in } \\
\text { multiple cell lines }\end{array}$ & $\begin{array}{l}\text { Metformin inhibited receptor tyrosine kinases, } \\
\text { inhibited cell-line growth and sensitized tumors to } \\
\text { paclitaxel in mouse models }\end{array}$ \\
\hline Liu et al. 2018 (47) & $\begin{array}{l}\text { Primary cultures from omental metastases } \\
\text { were treated with metformin and various } \\
\text { chemotherapeutic drugs }\end{array}$ & Metformin sensitized cancer cells to chemotherapy \\
\hline Ricci et al. 2019 (48) & $\begin{array}{l}\text { Cisplatin-resistant ovarian cancer } \\
\text { patient-derived xenograft models }\end{array}$ & $\begin{array}{l}\text { In vivo treatment with metformin partially reversed } \\
\text { platinum resistance }\end{array}$ \\
\hline Han et al. 2019 (39) & $\begin{array}{l}\text { Cisplatin-sensitive and resistant cells treated } \\
\text { with metformin }\end{array}$ & $\begin{array}{l}\text { Metformin re-sensitized cell lines to chemotherapy, } \\
\text { but only with functioning p53 }\end{array}$ \\
\hline
\end{tabular}

NF-kB, nuclear factor kappa-light-chain-enhancer of activated B cells.

or at least clearly above $2.7 \mu \mathrm{g} / \mathrm{L}(10 \mu \mathrm{M}$ range $)$, which has been reported to represent mean metformin plasma levels in metformin users (49). For example, in widely used SKOV3 ovarian cancer cells an IC50 value of $20 \mathrm{mmol} / \mathrm{l}$ has been reported for metformin (26). There is some evidence that even micromolar concentrations of metformin show synergy with chemotherapy in ovarian cancer cells, but only limited single-agent activity (35). On the other hand, metformin is not metabolized and relatively high metformin concentrations have also been found in tissues in vivo, especially in mitochondria. It may be argued that to achieve these such a concentrations and to study effects of metformin when administered over long period of treatments, millimolar metformin concentrations of metformin should be used in in vitro experiments (24). As a cation, metformin has a tendency to accumulate, especially within mitochondria, showing 100- to 500-fold concentrations (50). Nano-encapsulation of metformin into polymeric nanoparticles has been very recently developed in order to overcome metformin's poor cell-membrane permeability. This approach was shown to induce metformin cytotoxicity by reducing cell viability, and bringing cells to G2/M arrest, apoptotic morphological changes and alteration in the expression levels of several apoptotic genes and tumor suppressors $\mathrm{p} 53$ and hTERT in SKOV3 cells (51).

\section{Epidemiological studies}

\section{Incidence}

There are few register-based epidemiological studies focusing on the incidence of ovarian cancer in metformin users (Table 3). In the study by Tseng, a lower incidence of ovarian cancer was reported in women with type 2 diabetes (T2D) who were metformin ever-users [adjusted hazard ratio (aHR) 0.66, 95\% confidence interval (CI): 0.59-0.73] (53). 
Table 3 Incidence of ovarian cancer in metformin users among women with type 2 diabetes

\begin{tabular}{|c|c|c|c|c|c|}
\hline Authors, year & Design & $\begin{array}{l}\text { Region and } \\
\text { period }\end{array}$ & Patients & Reference group & Main results \\
\hline $\begin{array}{l}\text { Bodmer et al. } \\
2011(52)\end{array}$ & $\begin{array}{l}\text { Register-based } \\
\text { case-control }\end{array}$ & $\begin{array}{l}\text { UK } \\
\text { 1995-2009 }\end{array}$ & $\begin{array}{l}1,611 \text { ovarian cancers of } \\
\text { which } 85 \text { were in women } \\
\text { with T2D and } 41 \text { in } \\
\text { metformin users }\end{array}$ & $\begin{array}{l}\text { Women with } \\
\text { T2D and no prior } \\
\text { metformin use }\end{array}$ & $\begin{array}{l}\text { OR } 0.38 \text { (95\% Cl: } 0.18-0.81) \text { when } \\
\geq 10 \text { prescriptions of metformin } \\
\text { OR } 0.59 \text { ( } 95 \% \mathrm{Cl}: 0.25-1.41) \text { when } \\
<10 \text { prescriptions of metformin }\end{array}$ \\
\hline $\begin{array}{l}\text { Urpilainen et al. } \\
2018 \text { (54) }\end{array}$ & $\begin{array}{l}\text { Register-based } \\
\text { cohort and } \\
\text { case-control }\end{array}$ & $\begin{array}{l}\text { Finland } \\
1996-2011\end{array}$ & $\begin{array}{l}\text { Cohort size } 137,643 \text { with } \\
303 \text { ovarian cancer cases }\end{array}$ & $\begin{array}{l}\text { Women with T2D } \\
\text { using other oral } \\
\text { ADM }\end{array}$ & $\begin{array}{l}\text { Full cohort aHR } 1.02 \\
(95 \% \mathrm{Cl} 0.72-1.45) \\
\text { Case-control aHR } 0.91 \\
(95 \% \mathrm{Cl}: 0.61-1.34)\end{array}$ \\
\hline
\end{tabular}

T2D, type 2 diabetes; ADM, antidiabetic medication; OR, odds ratio; $\mathrm{Cl}$, confidence interval; aHR, adjusted hazard ratio.

However, in the study by Bodmer et al., only long-term (more than 10 prescriptions) metformin use seemed to have an association with a lower incidence of ovarian cancer, although this result was based on only 25 ovarian cancer cases (52). In publications that have reported the incidence of several types of cancer, in the ovarian cancer subgroup no association was found between metformin use and ovarian cancer incidence $(55,56)$. One of our own studies revealed no evidence of an association between metformin use and ovarian cancer incidence in women with $\mathrm{T} 2 \mathrm{D}$, not even with a cumulative metformin dose (54).

\section{Prognosis}

A few studies have shown a better prognosis of ovarian cancer in metformin users (57-59). In one study, favorable results were limited only to progression-free survival, and not seen in overall survival (60) (Table 4). However, the numbers of metformin users in these studies have been low, varying from 12 to 61 women. The more recent registerbased study on ovarian cancer prognosis did not reveal an association between prediagnostic metformin use and overall survival (62). In one of our own studies, findings were also inconclusive as regards an association between metformin use and survival after ovarian cancer in women with T2D (63).

\section{Clinical trials}

There are few clinical trials designed to evaluate metformin as therapeutic agent in ovarian cancer. At the moment, there are two recruiting and two completed clinical trials on ovarian cancer and metformin use (11). In a pilot study by Zheng et al., there were 20 ovarian cancer patients without a diagnosis of T2D receiving metformin along with adjuvant chemotherapy (paclitaxel and carboplatin) in first-line treatment of ovarian cancer (64). In this study, metformin use did not improve progression-free survival (PFS). However, modulation of the IGF-1 signaling axis was seen in the metformin group. Khawaja et al. have published a study in which patients with advanced or refractory cancer types were treated with an mTOR inhibitor, temsirolimus, in combination with metformin (65). With combination therapy a promising response with few side effects was achieved when assessing all cancers together. However, there were only two ovarian cancer cases in this study.

\section{Conclusions}

In preclinical studies, metformin has been found to have several direct and indirect mechanisms which make it antimitotic, anti-angiogenic, anti-inflammatory and a cellularenergy-state modifier. These cancer preventing assets are well-studied in ovarian cancer cells. However, the results of epidemiological studies are not as well defined. There is not enough evidence to verify the role of metformin as an ovarian cancer preventive drug. In addition, association between metformin and survival after ovarian cancer is complex. Thus, it is unlikely that metformin has an 
Table 4 Prognosis of ovarian cancer in metformin users among women with type 2 diabetes

\begin{tabular}{|c|c|c|c|c|c|}
\hline Authors, year & Design & $\begin{array}{l}\text { Country and } \\
\text { period }\end{array}$ & Patients & Reference group & Main results \\
\hline $\begin{array}{l}\text { Romero et al. } \\
2012(60)\end{array}$ & $\begin{array}{l}\text { Hospital-based } \\
\text { cohort }\end{array}$ & $\begin{array}{l}\text { USA } \\
1992-2010\end{array}$ & $\begin{array}{l}341 \text { ovarian cancers of which } \\
44 \text { were in women with T2D } \\
\text { and } 16 \text { in metformin users }\end{array}$ & $\begin{array}{l}\text { Women with T2D } \\
\text { without metformin } \\
\text { use }\end{array}$ & $\begin{array}{l}\text { PFS: HR } 0.38 \\
\text { (95\% Cl: } 0.16-0.90) \text {, } \\
\text { OS: HR } 0.43 \\
\text { (95\% Cl: } 0.16-1.19)\end{array}$ \\
\hline $\begin{array}{l}\text { Shah et al. } 2014 \\
(61)\end{array}$ & $\begin{array}{l}\text { Hospital-based } \\
\text { cohort }\end{array}$ & $\begin{array}{l}\text { USA } \\
2004-2009\end{array}$ & $\begin{array}{l}305 \text { women without DM and } \\
62 \text { women with T2D of which } \\
27 \text { were metformin users }\end{array}$ & $\begin{array}{l}\text { Women with T2D } \\
\text { and no use of } \\
\text { metformin }\end{array}$ & $\begin{array}{l}\text { PFS: metformin use } \\
10.1 \text { months vs. non-use } \\
10.3 \text { months } \\
\text { OS: metformin use } \\
23.9 \text { months vs. non-use } \\
26.1 \text { months }\end{array}$ \\
\hline $\begin{array}{l}\text { Bar et al. } 2016 \\
(57)\end{array}$ & $\begin{array}{l}\text { Hospital-based } \\
\text { cohort }\end{array}$ & $\begin{array}{l}\text { Israel } \\
2000-2012\end{array}$ & $\begin{array}{l}143 \text { ovarian cancers of which } \\
22 \text { were in women with T2D } \\
\text { and } 12 \text { in metformin users }\end{array}$ & $\begin{array}{l}\text { Women with T2D } \\
\text { without metformin } \\
\text { use }\end{array}$ & $\begin{array}{l}\text { RFS: HR } 0.14 \\
\text { (95\% Cl: 0.00-0.52) }\end{array}$ \\
\hline $\begin{array}{l}\text { Wang et al. } 2017 \\
\text { (59) }\end{array}$ & $\begin{array}{l}\text { Hospital-based } \\
\text { cohort }\end{array}$ & $\begin{array}{l}\text { China } \\
\text { 2011-2014 }\end{array}$ & $\begin{array}{l}568 \text { ovarian cancer cases of } \\
\text { which } 48 \text { in metformin users }\end{array}$ & $\begin{array}{l}\text { Women with T2D } \\
\text { without metformin } \\
\text { use }\end{array}$ & $\begin{array}{l}\text { PFS HR } 0.34 \\
(95 \% \mathrm{Cl}: 0.27-0.67) \\
\text { OS HR } 0.29 \\
(95 \% \mathrm{Cl}: 0.13-0.58)\end{array}$ \\
\hline $\begin{array}{l}\text { Garcia et al. } 2017 \\
(62)\end{array}$ & $\begin{array}{l}\text { Register-based } \\
\text { cohort and nested } \\
\text { case-control }\end{array}$ & $\begin{array}{l}\text { USA } \\
2007-2011\end{array}$ & $\begin{array}{l}2,291 \text { ovarian cancers of } \\
\text { which } 552 \text { were in women } \\
\text { with T2D and } 172 \text { in } \\
\text { metformin users }\end{array}$ & $\begin{array}{l}\text { Women without } \\
\text { metformin use, also } \\
\text { including women } \\
\text { without T2D }\end{array}$ & $\begin{array}{l}\text { OS: HR } 0.96 \\
(95 \% \mathrm{Cl}: 0.75-1.23)\end{array}$ \\
\hline
\end{tabular}

T2D, type 2 diabetes; DM, diabetes mellitus; ADM, antidiabetic medication; PFS, progression-free survival; HR, hazard ratio; Cl, confidence interval; OS, overall survival; RFS, recurrence-free survival; OC, ovarian cancer.

anticancer role as monotherapy. Hopefully, ongoing clinical trials will more specifically clarify the role of metformin in ovarian cancer treatment in the near future.

\section{Acknowledgments}

Funding: This project was supported by the Jane and Aatos Erkko Foundation (grant number T59127), the Cancer Society of Finland (T59129) and Finnish Government Research Funds granted to the University Hospital of Oulu.

\section{Footnote}

Provenance and Peer Review: This article was commissioned by the Guest Editors (Stergios Boussios and Nicholas Pavlidis) for the series "Ovarian Cancer: State of the Art and Perspectives of Clinical Research" published in Annals of Translational Medicine. The article was sent for external peer review organized by the Guest Editors and the editorial office.

Conflicts of Interest: All authors have completed the ICMJE 
uniform disclosure form (available at http://dx.doi. org/10.21037/atm-20-1060). The series "Ovarian Cancer: State of the Art and Perspectives of Clinical Research" was commissioned by the editorial office without any funding or sponsorship. SB serves as an unpaid editorial board member of Annals of Translational Medicine from Nov 2019 to Oct 2021. EU reports grants from The Cancer Society of Finland, during the conduct of the study. UP reports grants from Jane and Aatos Erkko Foundation, during the conduct of the study. The other authors have no conflicts of interest to declare.

Ethical Statement: The authors are accountable for all aspects of the work in ensuring that questions related to the accuracy or integrity of any part of the work are appropriately investigated and resolved.

Open Access Statement: This is an Open Access article distributed in accordance with the Creative Commons Attribution-NonCommercial-NoDerivs 4.0 International License (CC BY-NC-ND 4.0), which permits the noncommercial replication and distribution of the article with the strict proviso that no changes or edits are made and the original work is properly cited (including links to both the formal publication through the relevant DOI and the license). See: https://creativecommons.org/licenses/by-nc-nd/4.0/.

\section{References}

1. Romero R, Erez O, Huttemann M, et al. Metformin, the aspirin of the 21 st century: its role in gestational diabetes mellitus, prevention of preeclampsia and cancer, and the promotion of longevity. Am J Obstet Gynecol 2017;217:282-302.

2. Watanabe CK. Studies in the metabolism changes induced by administration of guanidine bases: I. Influence of injected guanide hydrochloride upon blood sugar content. J Biol Chem 1918;33:253-65.

3. Sterne J. Du nouveau dans les antidiabetiques. La NN dimethylamine guanyl guanide (NNDG). Maroc Med 1957;36:1295-6.

4. Flory J, Lipska K. Metformin in 2019. JAMA 2019;321:1926-7.

5. Kobayashi Y, Banno K, Kunitomi H, et al. Current state and outlook for drug repositioning anticipated in the field of ovarian cancer. J Gynecol Oncol 2019;30:1:e10.

6. Skrott Z, Mitstrik M, Andersen KK, et al. Alcohol-abuse drug disulfiram targets cancer via p97 segregase adaptor
NPL4. Nature 2017;552:194-9.

7. Qiu X, Ma J, Wang K, et al. Chemopreventive effects of 5-aminosalicylic acid on inflammatory bowel diseaseassociated colorectal cancer and dysplasia: a systematic review with meta-analysis. Oncotarget 2017;8:1031-45.

8. Aljofan M, Riethmacher D. Anticancer activity of metformin: a systematic review of the literature. Future Sci OA 2019;5:FSO410.

9. Dil'man VM, Bershtein LM, Zabezhinskii MA, et al. Effect of phenformin on mammary gland tumor induction in rats. Vopr Onkol 1974;20:94-8.

10. Evans JM, Donnelly LA, Emslie-Smith AM, et al. Metformin and reduced risk of cancer in diabetic patients. BMJ 2005;330:1304-5.

11. Clinical Trials. Available online: https://clinicaltrials.gov. Accessed 29.4. 2019.

12. Sośnicki S, Kapral M, Weglarz L. Molecular targets of metformin antitumor action. Pharmacol Rep 2016;68:918-25.

13. Dowling RJ, Goodwin PJ, Stambolic V. Understanding the benefit of metformin use in cancer treatment. BMC Med 2011;9:33.

14. Morales DR, Morris AD. Metformin in cancer treatment and prevention. Annu Rev Med 2015;66:17-29.

15. Viollet B, Guigas B, Sanz Garcia N, et al. Cellular and molecular mechanisms of metformin: an overview. Clin Sci (Lond) 2012;122:253-70.

16. Pollak M. The insulin and insulin-like growth factor receptor family in neoplasia: an update. Nat Rev Cancer 2012;12:159-69.

17. Yi Y, Zhang W, Yi J, et al. Role of p53 Family Proteins in Metformin Anti-Cancer Activities. J Cancer 2019;10:2434-42.

18. Gadducci A, Biglia N, Tana R, et al. Metformin use and gynecological cancers: a novel treatment option emerging from drug repositioning. Crit Rev Oncol Hematol 2016;105:73-83.

19. Aljada A, Mousa SA. Metformin and neoplasia: implications and indications. Pharmacol Ther 2012;133:108-15.

20. Patel S, Kumar L, Singh N. Metformin and epithelial ovarian cancer therapeutics. Cell Oncol (Dordr) 2015;38:365-75.

21. Chen HP, Shieh JJ, Chang CC, et al. Metformin decreases hepatocellular carcinoma risk in a dosedependent manner: population-based and in vitro studies. Gut 2013;62:606-15.

22. Shank JJ, Yang K, Ghannam J, et al. Metformin targets ovarian cancer stem cells in vitro and in vivo. Gynecol 
Oncol 2012;127:390-7.

23. Kim NY, Lee HY, Lee C. Metformin targets Axl and Tyro3 receptor tyrosine kinases to inhibit cell proliferation and overcome chemoresistance in ovarian cancer cells. Int J Oncol 2015;47:353-60.

24. Patel S, Singh N, Kumar L. Evaluation of Effects of Metformin in Primary Ovarian Cancer Cells. Asian Pac J Cancer Prev 2015;16:6973-9.

25. Huo J, Bian XH, Huang Y, et al. Inhibitory effect and mechanism of metformin on human ovarian cancer cells SKOV-3 and A2780. Eur Rev Med Pharmacol Sci 2017;21:484-9.

26. Fu YL, Zhang QH, Wang XW, et al. Antidiabetic drug metformin mitigates ovarian cancer SKOV3 cell growth by triggering $\mathrm{G} 2 / \mathrm{M}$ cell cycle arrest and inhibition of m-TOR/PI3K/Akt signaling pathway. Eur Rev Med Pharmacol Sci 2017;21:1169-75.

27. Erices R, Cubillos S, Aravena R, et al. Diabetic concentrations of metformin inhibit plateletmediated ovarian cancer cell progression. Oncotarget 2017;8:20865-80.

28. Zhang F, Chen H, Du J, et al. Anticancer Activity of Metformin, an Antidiabetic Drug, Against Ovarian Cancer Cells Involves Inhibition of Cysteine-Rich 61 (Cyr61)/ Akt/Mammalian Target of Rapamycin (mTOR) Signaling Pathway. Med Sci Monit 2018;24:6093-101.

29. Ma L, Wei J, Wan J, et al. Low glucose and metformininduced apoptosis of human ovarian cancer cells is connected to ASK1 via mitochondrial and endoplasmic reticulum stress-associated pathways. J Exp Clin Cancer Res 2019;38:77-6.

30. Zou G, Bai J, Li D, et al. Effect of metformin on the proliferation, apoptosis, invasion and autophagy of ovarian cancer cells. Exp Ther Med 2019;18:2086-94.

31. Lengyel E, Litchfield LM, Mitra AK, et al. Metformin inhibits ovarian cancer growth and increases sensitivity to paclitaxel in mouse models. Am J Obstet Gynecol 2015;212:479.e1-479.e10.

32. Dang JH, Jin ZJ, Liu XJ, et al. Metformin in combination with cisplatin inhibits cell viability and induces apoptosis of human ovarian cancer cells by inactivating ERK 1/2. Oncol Lett 2017;14:7557-64.

33. Wu B, Li S, Sheng L, et al. Metformin inhibits the development and metastasis of ovarian cancer. Oncol Rep 2012;28:903-8.

34. Liao H, Zhou Q, Gu Y, et al. Luteinizing hormone facilitates angiogenesis in ovarian epithelial tumor cells and metformin inhibits the effect through the mTOR signaling pathway. Oncol Rep 2012;27:1873-8.

35. Erices R, Bravo ML, Gonzalez P, et al. Metformin, at concentrations corresponding to the treatment of diabetes, potentiates the cytotoxic effects of carboplatin in cultures of ovarian cancer cells. Reprod Sci 2013;20:1433-46.

36. Zhang R, Zhang $\mathrm{P}$, Wang $\mathrm{H}$, et al. Inhibitory effects of metformin at low concentration on epithelial-mesenchymal transition of CD44(+)CD117(+) ovarian cancer stem cells. Stem Cell Res Ther 2015;6:262.

37. Yasmeen A, Beauchamp MC, Piura E, et al. Induction of apoptosis by metformin in epithelial ovarian cancer: involvement of the Bcl-2 family proteins. Gynecol Oncol 2011;121:492-8.

38. Bishnu A, Sakpal A, Ghosh N, et al. Long term treatment of metformin impedes development of chemoresistance by regulating cancer stem cell differentiation through taurine generation in ovarian cancer cells. Int J Biochem Cell Biol 2019;107:116-27.

39. Han CY, Patten DA, Lee SG, et al. p53 Promotes chemoresponsiveness by regulating hexokinase II gene transcription and metabolic reprogramming in epithelial ovarian cancer. Mol Carcinog 2019;58:2161-74.

40. Ahmed AA, Etemadmoghadam D, Temple J, et al. Driver mutations in TP53 are ubiquitous in high grade serous carcinoma of the ovary. J Pathol 2010;221:49-56.

41. Yang C, Zhao N, Li D, et al. Metformin improves the sensitivity of ovarian cancer cells to chemotherapeutic agents. Oncol Lett 2019;18:2404-11.

42. McGuire WP, Hoskins WJ, Brady MF, et al. Cyclophosphamide and cisplatin compared with paclitaxel and cisplatin in patients with stage III and stage IV ovarian cancer. N Engl J Med 1996;334:1-6.

43. Colombo N, Sessa C, du Bois A, et al. ESMO-ESGO consensus conference recommendations on ovarian cancer: pathology and molecular biology, early and advanced stages, borderline tumours and recurrent disease. Ann Oncol 2019;30:672-705.

44. Gotlieb WH, Saumet J, Beauchamp MC, et al. In vitro metformin anti-neoplastic activity in epithelial ovarian cancer. Gynecol Oncol 2008;110:246-50.

45. Zheng Y, Zhu J, Zhang H, et al. Metformin inhibits ovarian cancer growth and migration in vitro and in vivo by enhancing cisplatin cytotoxicity. Am J Transl Res 2018;10:3086-98.

46. Dos Santos Guimarães I, Ladislau-Magescky T, Tessarollo NG, et al. Chemosensitizing effects of metformin on cisplatin- and paclitaxel-resistant ovarian cancer cell lines. Pharmacol Rep 2018;70:409-17. 
47. Liu Y, Feng Y, Liu H, et al. Real-time assessment of platinum sensitivity of primary culture from a patient with ovarian cancer with extensive metastasis and the platinum sensitivity enhancing effect by metformin. Oncol Lett 2018;16:4253-62.

48. Ricci F, Brunelli L, Affatato R, et al. Overcoming platinum-acquired resistance in ovarian cancer patient-derived xenografts. Ther Adv Med Oncol 2019;11:1758835919839543.

49. Lalau JD, Lemaire-Hurtel AS, Lacroix C. Establishment of a database of metformin plasma concentrations and erythrocyte levels in normal and emergency situations. Clin Drug Investig 2011;31:435-8.

50. Chandel NS, Avizonis D, Reczek CR, et al. Are Metformin Doses Used in Murine Cancer Models Clinically Relevant? Cell Metab 2016;23:569-70.

51. Faramarzi L, Dadashpour M, Sadeghzadeh H, et al. Enhanced anti-proliferative and pro-apoptotic effects of metformin encapsulated PLGA-PEG nanoparticles on SKOV3 human ovarian carcinoma cells. Artif Cells Nanomed Biotechnol 2019;47:737-46.

52. Bodmer M, Becker C, Meier C, et al. Use of metformin and the risk of ovarian cancer: a case-control analysis. Gynecol Oncol 2011;123:200-4.

53. Tseng CH. Metformin reduces ovarian cancer risk in Taiwanese women with type 2 diabetes mellitus. Diabetes Metab Res Rev 2015;31:619-26.

54. Urpilainen E, Marttila M, Hautakoski A, et al. The role of metformin and statins in the incidence of epithelial ovarian cancer in type 2 diabetes: a cohort and nested case-control study. BJOG 2018;125:1001-8.

55. Baur DM, Klotsche J, Hamnvik OP, et al. Type 2 diabetes mellitus and medications for type 2 diabetes mellitus are associated with risk for and mortality from cancer in a German primary care cohort. Metabolism 2011;60:1363-71.

56. Home PD, Kahn SE, Jones NP, et al. Experience of malignancies with oral glucose-lowering drugs in the randomised controlled ADOPT (A Diabetes Outcome

Cite this article as: Urpilainen E, Puistola U, Boussios S, Karihtala P. Metformin and ovarian cancer: the evidence. Ann Transl Med 2020;8(24):1711. doi: 10.21037/atm-20-1060
Progression Trial) and RECORD (Rosiglitazone Evaluated for Cardiovascular Outcomes and Regulation of Glycaemia in Diabetes) clinical trials. Diabetologia 2010;53:1838-45.

57. Bar D, Lavie O, Stein N, et al. The effect of metabolic comorbidities and commonly used drugs on the prognosis of patients with ovarian cancer. Eur J Obstet Gynecol Reprod Biol 2016;207:227-31.

58. Kumar S, Meuter A, Thapa P, et al. Metformin intake is associated with better survival in ovarian cancer: a casecontrol study. Cancer 2013;119:555-62.

59. Wang SB, Lei KJ, Liu JP, et al. Continuous use of metformin can improve survival in type 2 diabetic patients with ovarian cancer: A retrospective study. Medicine (Baltimore) 2017;96:e7605.

60. Romero IL, McCormick A, McEwen KA, et al. Relationship of type II diabetes and metformin use to ovarian cancer progression, survival, and chemosensitivity. Obstet Gynecol 2012;119:61-7.

61. Shah MM, Erickson BK, Matin T, et al. Diabetes mellitus and ovarian cancer: more complex than just increasing risk. Gynecol Oncol 2014;135:273-7.

62. Garcia C, Yao A, Camacho F, et al. A SEER-Medicare analysis of the impact of metformin on overall survival in ovarian cancer. Gynecol Oncol 2017;146:346-50.

63. Urpilainen E, Marttila M, Hautakoski A, et al. Prognosis of ovarian cancer in women with type 2 diabetes using metformin and other forms of antidiabetic medication or statins: a retrospective cohort study. BMC Cancer 2018;18:767.

64. Zheng Y, Zhu J, Zhang H, et al. Metformin plus first-line chemotherapy versus chemotherapy alone in the treatment of epithelial ovarian cancer: a prospective open-label pilot trial. Cancer Chemother Pharmacol 2019;84:1349-57.

65. Khawaja MR, Nick AM, Madhusudanannair V, et al. Phase I dose escalation study of temsirolimus in combination with metformin in patients with advanced/refractory cancers. Cancer Chemother Pharmacol 2016;77:973-7. 